\title{
Efficacy of acid treatments used in archaeological ceramics for the removal of calcareous deposits
}

\author{
Águeda Sáenz-Martínez ${ }^{1, \mathrm{a}}{ }_{\mathbb{D}}$, Marta Pérez-Estébanez $^{1}{ }_{\mathbb{D}}$, Margarita San $_{\text {Andrés }}{ }^{1}$ (D), \\ Mónica Alvarez de Buergo ${ }^{2}$ (D), Rafael Fort ${ }^{2}$ (D) \\ ${ }^{1}$ Departamento de Pintura y Conservación-Restauración, Facultad de Bellas Artes, Universidad Complutense \\ de Madrid (UCM), C/ Pintor el Greco 2, 28040 Madrid, Spain \\ 2 Instituto de Geociencias IGEO (Consejo Superior de Investigaciones Científicas y Universidad Complutense \\ de Madrid), C/ Doctor Severo Ochoa 7, 28040 Madrid, Spain
}

Received: 6 November 2020 / Accepted: 21 July 2021

(C) The Author(s) 2021

\begin{abstract}
Calcareous deposits are one of the most common alterations that archaeological ceramics can exhibit, and they can damage their artistic and historical values. For this reason, it becomes necessary to remove these deposits. However, there is no agreement in the conservation field about the conditions of the cleaning treatments. Moreover, little has been studied about the consequences that archaeological ceramics might suffer. The main purpose of this research is to study the efficacy and safety of several cleaning treatments that are or can be used in archaeological ceramics. To this aim, it was necessary, in first place, elaborating ceramic specimens, simulating archaeological ones, and artificially growing calcareous deposits on their surface. Afterwards, effective and little damaging cleaning treatments based on the immersion of the elaborated ceramics on acid products were developed. Acetic and nitric acid solutions were prepared at the minimum concentration and applied during the minimum time to be effective. Ceramic specimens were elaborated with a commercial red clay simulating archaeological ceramics to avoid trials on real cultural objects. The mineralogical composition of the ceramics was studied by X-ray powder diffraction to establish if changes occurred after the carbonation process and after the cleaning treatments, and thermogravimetric analysis allowed to quantify the calcium carbonate content in every step of the process and to determine the efficacy and safety of such cleaning treatments. According to the results obtained so far, the acid treatments (acetic and nitric acid) were both effective in the removal of the deposits and did not modify the initial mineralogical composition of the ceramic specimens. Besides, no significant differences among them were detected regarding their efficacy.
\end{abstract}

\section{Introduction}

Archaeological ceramics are, from an historical point of view, very relevant materials as the information they possess help historians to understand the societies from the past. In this way, archaeological ceramics provide data regarding the technological development of these societies. This includes information about the raw materials used, how they were

\footnotetext{
a e-mail: agsaenz@ucm.es (corresponding author)
} 
prepared, how and by whom they were modelled, how they were fired (temperature and atmosphere), and what they were used for (cooking, food storage, rituals...) [1]. Besides, the physical and chemical features make archaeological ceramics very resistant materials, in comparison with glass or organic materials such as wood [2]. However, they can present several alterations: material loss, cracking, decoration loss, etc. Among them, soluble and insoluble salts deposits are the most common ones, both in buried and underwater finds. Indeed, calcareous deposits not only appear on buried ceramics, as underwater materials also present deposits from calcareous shells of marine animals [3]. Whereas soluble salts are easy to remove by immersion in water, the removal of insoluble salts implies the use of chemical products that soften the deposits. For example, calcium carbonate is very difficult to remove mechanically or dissolve in water due to its low solubility $\left(\mathrm{CaCO}_{3} k_{\mathrm{ps}}=4.8 \times 10^{-9}\right)$ [4]. Even though current trends in the conservation-restoration field are more respectful and tend to leave them under controlled ambient conditions [5], sometimes, their removal becomes necessary. For example, if the deposits imply an information loss, by covering a piece of decoration or some writing. Also, if the pieces are going to be exhibited, their aesthetic values become fundamental and the deposits might interfere with their appreciation.

For the removal of these deposits, since the 70s, conservators have developed and performed several treatments, based on acid and basic solutions to soften the deposits, followed by a mechanical action $[1,6]$. Regarding the application methods, direct, as immersion, and indirect, as poultices, are the most common ones [7-10]. Indirect application methods are, in general, easier to control, as they release the product contained in a more gradual way. They are also meant to be safer than direct ones, as more specific areas can be treated. For this reason, other products were developed from the 80s onwards for indirect methods: the thickening agents. Since then, they became quite common in the conservation-restoration field. However, they are still not usual in the conservation of archaeological objects [11-15]. Within this research project, a survey among 54 Spanish conservators was conducted in 2018 in order to know more about current treatments. According to the data obtained, poultices (70.4\%), gels (37\%) and static baths $(22.2 \%)$ were the three most common application methods used for the removal of calcareous deposits, among others. Poultices can be made of clay, cellulose or cotton, whereas gels consist of agarose, polyacrylic acid, xanthan gum or other polymers. On the other hand, static baths consist of the immersion of the pieces in the selected product without adding movement. Regarding products, acids (55.6\%) and chelating agents (74.1\%) resulted the most usual ones. Finally, for the removal of the possible remains, or neutralisation process, the most common method is the immersion or static bath in distilled or deionised water, alone $(70.9 \%$ ) or combined with other products (buffers, basic solutions, etc.) $(16.4 \%)[16]$.

It is important to bear in mind that, in the same way that the products applied to remove insoluble deposits are effective, they might be also altering the minerals contained in the ceramics matrixes. More specifically, carbonates, such as calcium carbonate $\left(\mathrm{CaCO}_{3}\right)$ or dolomite $\left[\mathrm{CaMg}\left(\mathrm{CO}_{3}\right)_{2}\right]$, might be dissolved by the effect of acid and chelating agents. Even though some studies proved that acid products may affect the original composition of the ceramics, they are still in use [17-19]. In order to guarantee the safety of the ceramic pieces treated with these products, it becomes essential to analyse their effects on these materials, as they might be harmful and imply severe and irreversible consequences to the conservation of the ceramics.

This research aims to study the efficacy and safety of acid products applied by immersion in the removal of calcareous deposits, by determining the mineralogy composition by XRPD and the quantification of calcium carbonate by TG-DSC. For this purpose, a methodology 
for the elaboration of ceramic specimens and the growth of calcareous deposits has been developed.

\section{Materials and methods}

\subsection{Ceramic specimens}

Four groups of ceramic specimens, fired at four different temperatures, were elaborated in order to simulate archaeological ceramics with different properties [20]. A red commercial clay Sio- $2^{\circledR}$ ARGILA (Ceramica Collet S.A.) was used for its similarity with red natural clays, one of the most common clays used for ceramics since ancient times, due to its easy accessibility and natural plastic properties $[21,22]$. No tempers or water were added during its manipulation. Its chemical composition established by XRF was provided by the supplier enterprise J. L. Vicentiz, S. L. According to the results expressed in oxides (Table 1), the main components of the red clay used are silicon oxide $\left(\mathrm{SiO}_{2}\right)$ and aluminium oxide $\left(\mathrm{Al}_{2} \mathrm{O}_{3}\right)$, in minor concentration iron, calcium, potassium and magnesium oxides were detected $\left(\mathrm{Fe}_{2} \mathrm{O}_{3}\right.$; $\mathrm{CaO} ; \mathrm{K}_{2} \mathrm{O} ; \mathrm{MgO}$; respectively). Other components were also found: titanium, sodium and manganese oxides $\left(\mathrm{TiO}_{2} ; \mathrm{Na}_{2} \mathrm{O} ; \mathrm{MnO}\right)$. These results were verified and completed, so they could be used as a reference in the research. Besides, its mineralogical composition was established by XRPD and oriented aggregates patterns (OA) (see "Results and discussion" section).

Layers of $1 \mathrm{~cm}$ thick of clay were cut and flattened using a rolling pin, without hand modelling, and later cut into approx. squares of $5 \mathrm{~cm}$ side (Fig. 1a, b). The specimens were let dry in a climatic chamber (Vötsch Indusrietechnik VCL 4010) at a temperature of $20{ }^{\circ} \mathrm{C}$ and $50 \%$ of relative humidity (RH) (Fig. 1c). After $5 \mathrm{~h}$, they were turned around to allow a homogeneous drying process, and $72 \mathrm{~h}$ later, the specimens were introduced into a muffle furnace (SNOL 30/1300 L) and fired up to $120{ }^{\circ} \mathrm{C}$ at a heating rate of $2{ }^{\circ} \mathrm{C} / \mathrm{min}$ and $5 \mathrm{~min}$ soak to eliminate hygroscopic water [23].

Afterwards, the specimens were introduced again into the climatic chamber at $20{ }^{\circ} \mathrm{C}$ and $50 \% \mathrm{RH}$ to cool them down. In order to reproduce archaeological firing temperatures, the specimens were fired up to $650,800,1000$ and $1100{ }^{\circ} \mathrm{C}$ at a heating rate of $2{ }^{\circ} \mathrm{C} / \mathrm{min}$ and $3 \mathrm{~h}$ soak (Fig. 1d). Once cooled down in the muffle furnace under $100^{\circ} \mathrm{C}$, they were introduced into the climatic chamber at $20^{\circ} \mathrm{C}$ and $50 \% \mathrm{RH}$ for $24 \mathrm{~h}$ (Fig. 1e).

\subsection{Artificially growth of calcareous deposits}

Subsequently, to favour the growth of calcareous deposits on the ceramic specimens' surfaces, a specific methodology was developed. A lime putty of four years maturation time (supplied by Proiescon S.L.) and limewater obtained from it were used for the growth of calcium

Table 1 XRF results expressed in oxides of the red commercial clay used for the elaboration of the ceramic specimens. L.O.I.: Loss on Ignition. Analysis provided by J.L. Vincentiz S.L

\begin{tabular}{llllllllll}
\hline \multicolumn{1}{l}{ Oxides $\%$} \\
\hline $\mathrm{SiO}_{2}$ & $\mathrm{Al}_{2} \mathrm{O}_{3}$ & $\mathrm{Fe}_{2} \mathrm{O}_{3}$ & $\mathrm{CaO}$ & $\mathrm{K}_{2} \mathrm{O}$ & $\mathrm{MgO}$ & $\mathrm{TiO}_{2}$ & $\mathrm{Na}_{2} \mathrm{O}$ & $\mathrm{MnO}$ & L.O.I \\
\hline 53.90 & 17.60 & 6.33 & 5.41 & 3.63 & 2.67 & 0.86 & 0.30 & 0.11 & 8.90 \\
\hline
\end{tabular}



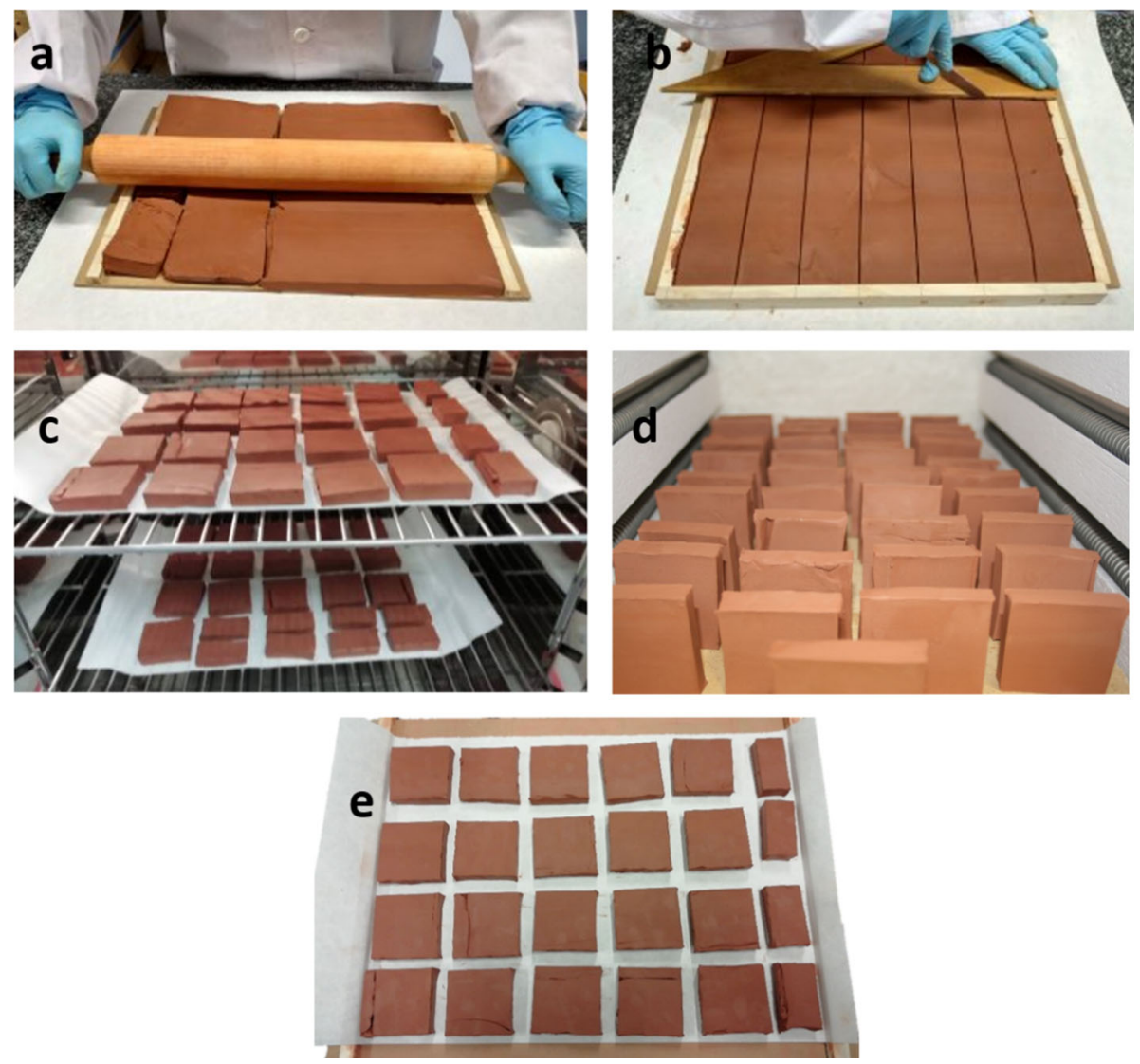

Fig. 1 Elaboration of the ceramic specimens, including the modelling of the clay (a), the shaping of the specimens (b), their drying in climatic chamber $(\mathbf{c})$, the firing process $(\mathbf{d})$ and the final specimens $(\mathbf{e})$

carbonate deposits on the surface of the specimens, together with dried and sieved soil (250-63 $\mu \mathrm{m})$ from the archaeological site of Guarrazar (Toledo, Spain). Its mineralogical composition was studied by XRPD and oriented aggregates (see "Results and discussion" section). In first place, the fired ceramic specimens were introduced into a lime water bath (3:1 vol.) for 7 days (Fig. 2a). Afterwards, a layer $2-3 \mathrm{~mm}$ thick of lime putty mixed with the sieved soil (3:1 vol.) was applied on the surface (Fig. 2c). To end with, the pieces were introduced for 10 days into a climatic chamber (Dycometal CCK -25/81) at $20{ }^{\circ} \mathrm{C}, 60 \%$ $\mathrm{RH}$ and $1600 \mathrm{ppm} \mathrm{CO}_{2}$, conditions that favoured the carbonation process of the deposits previously applied (Fig. 2d). The resulted deposits presented more adherence in the pieces fired up to higher temperatures $\left(1000\right.$ and $\left.1100{ }^{\circ} \mathrm{C}\right)$ than those fired to lower ones $(650$ and $800^{\circ} \mathrm{C}$ ) (Fig. 2e). For these last lower temperatures, a white veiling accumulation appeared underneath the lime putty deposit because of the immersion in lime water that hampered a high adhesion of the lime putty to the ceramic surface (Fig. 2b). Due to this lack of adhesion, some of the growth deposits shown craquelure on their surfaces (Fig. 2e). 

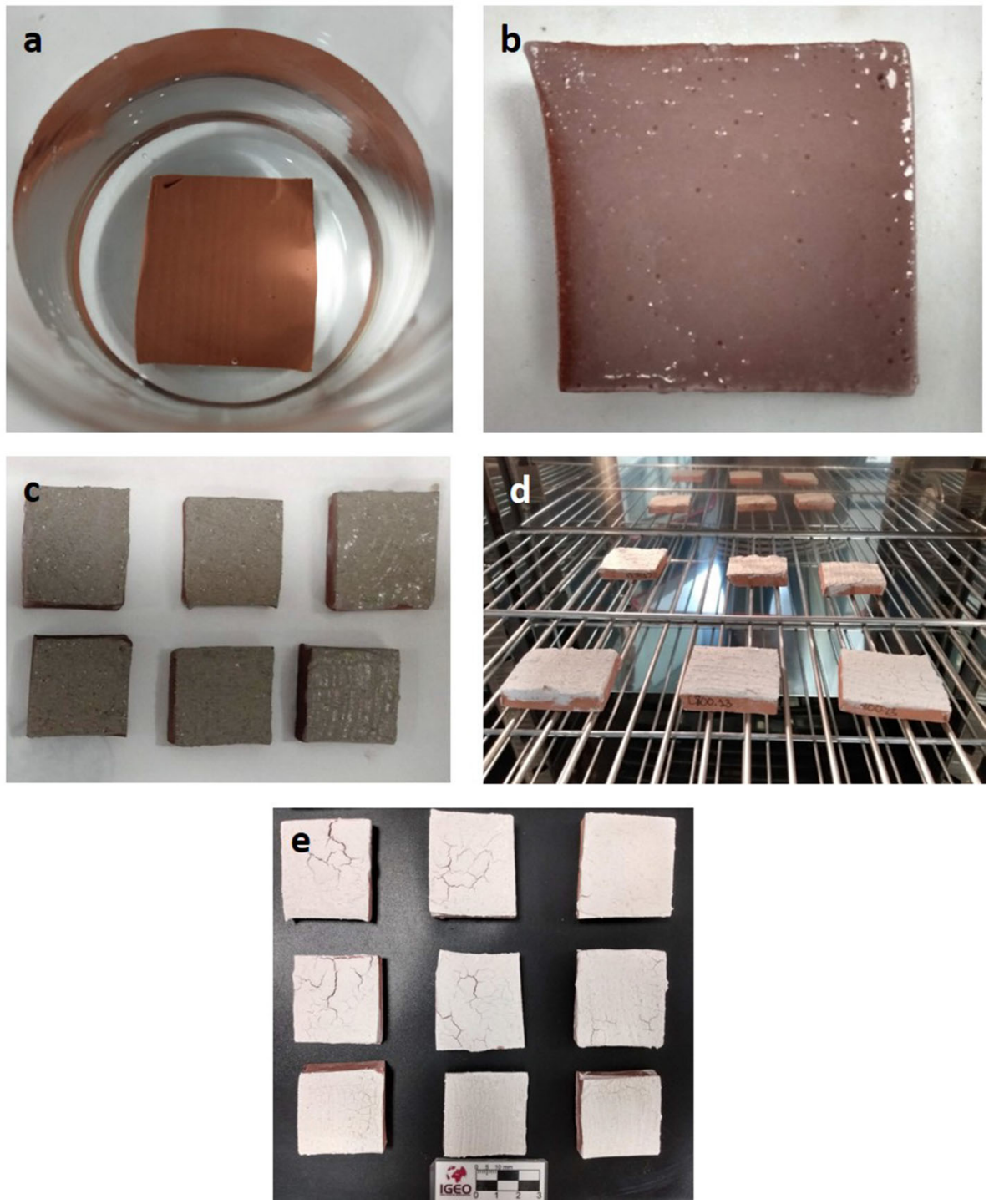

Fig. 2 Artificially growth of the calcareous deposits on the surfaces of the ceramic specimens. First the immersion in limewater (a, b), followed by the application of the mixture of lime putty and sieved soil (c), the carbonation process in the climatic chamber (d) and the deposits obtained (e)

\subsection{Cleaning treatments}

In order to remove the artificially grown calcareous deposits, two acids, the most used in archaeological ceramics, according to the survey conducted, were tested: acetic acid $\left(\mathrm{CH}_{3} \mathrm{COOH}\right.$, AA for short), a weak acid, and nitric acid $\left(\mathrm{HNO}_{3}\right.$, NA for short), a strong one. Acids react with calcium carbonate and transform it into the soluble salts: calcium acetate and calcium nitrate, respectively. After that, the deposits are easily removed by mechanical means. The occurring chemical reactions during this process are the following: 
Table 2 Characteristics and conditions of the acid treatments, both acetic acid and nitric acid at $1 \%$ vol., applied by immersion to the ceramic specimens

\begin{tabular}{lcllll}
\hline Acronym & Firing temperature $\left({ }^{\circ} \mathrm{C}\right)$ & Acid & $\mathrm{pH}$ & Treatment time 1 & Treatment time 2 \\
\hline C650 AA & \multirow{2}{*}{650} & Acetic & 2.76 & $30^{\prime}$ & \\
C650 NA & & Nitric & 1.16 & & \\
C800 AA & \multirow{2}{*}{800} & Acetic & 2.76 & & $10^{\prime}$ \\
C800 NA & & Nitric & 1.16 & & \\
C1000 AA & \multirow{2}{*}{1000} & Acetic & 2.76 & & $10^{\prime}$ \\
C1000 NA & & Nitric & 1.16 & & $10^{\prime}$ \\
C1100 AA & \multirow{2}{*}{1100} & Acetic & 2.76 & & \\
C1100 NA & & Nitric & 1.16 &
\end{tabular}

The acronyms gathered correspond, in first place, to the firing temperature of each specimen treated followed by the letters of the cleaning treatment used (AA for acetic acid, and NA for nitric acid, both by immersion or static bath)

$$
\begin{gathered}
\mathrm{CaCO}_{3}+2 \mathrm{CH}_{3} \mathrm{COOH} \rightarrow \mathrm{Ca}\left(\mathrm{CH}_{3} \mathrm{COO}\right)_{2}+\mathrm{CO}_{2}+\mathrm{H}_{2} \mathrm{O} \\
\mathrm{CaCO}_{3}+2 \mathrm{HNO}_{3} \rightarrow \mathrm{Ca}\left(\mathrm{NO}_{3}\right)_{2}+\mathrm{CO}_{2}+\mathrm{H}_{2} \mathrm{O}
\end{gathered}
$$

According to the Spanish standard UNE 41806-2 IN: 2009 [24], minimum concentration of the products and shortest treatment were set as basic criteria for the cleaning treatments. For this reason, solutions of the acids were prepared at $1 \%$ vol. in deionised water. The $\mathrm{pH}$ values were set as $2.76 \pm 0.01$ for acetic acid and $1.16 \pm 0.01$ for nitric acid (measured with a Seven Compact pH meter S220 METTLER TOLEDO, sounding line InLab ${ }^{\circledR}$ Expert Pro-ISM). After several tests, $30 \mathrm{~min}$ was set as the minimum time for the treatments to be effective. One ceramic specimen of each firing temperature $\left(650,800,1000\right.$ and $\left.1100{ }^{\circ} \mathrm{C}\right)$ was introduced in $300 \mathrm{~mL}$ of each acid solution for at least $30 \mathrm{~min}$. Afterwards, the existing remains of the deposits were mechanically removed with wooden sticks. Table 2 shows the samples obtained at various temperatures and tested with different acid solutions to clean the calcareous deposits. Three of the specimens (C800 NA, C1100 AA, C1100 NA) needed additional time to soften the deposits, so the chemical treatment was repeated for 10 more minutes (Table 2). Specimens after the cleaning treatments are shown in Fig. 4. As can be noticed, the possible remains of the deposit no longer interfere in the appreciation of any of the ceramics (Fig. 3).

After the treatments, it was necessary to neutralise their effect and remove the soluble salts resulted from them. The neutralisation process was made by immersion in deionised water $(\mathrm{pH} \approx 6-7)$, in an approximated ratio of $1: 15 \mathrm{~g} / \mathrm{mL}$ [25]. To monitor this neutralisation process, conductivity measures $(K)$ were recorded with an electrical conductivity meter (Delta-Ohm HD2156.2) at 0, 5, 10, 15, 30, 60, 120, $180 \mathrm{~min}$. To establish the endpoint of the neutralisation process, the variation in $K_{\text {norm }}$ was monitored, as it considers the change in conductivity, regarding the water volume, time and mass of the specimen as follows [25, 26]:

$$
K_{\mathrm{norm}}=\frac{\Delta K \times L}{\Delta t \times g}
$$




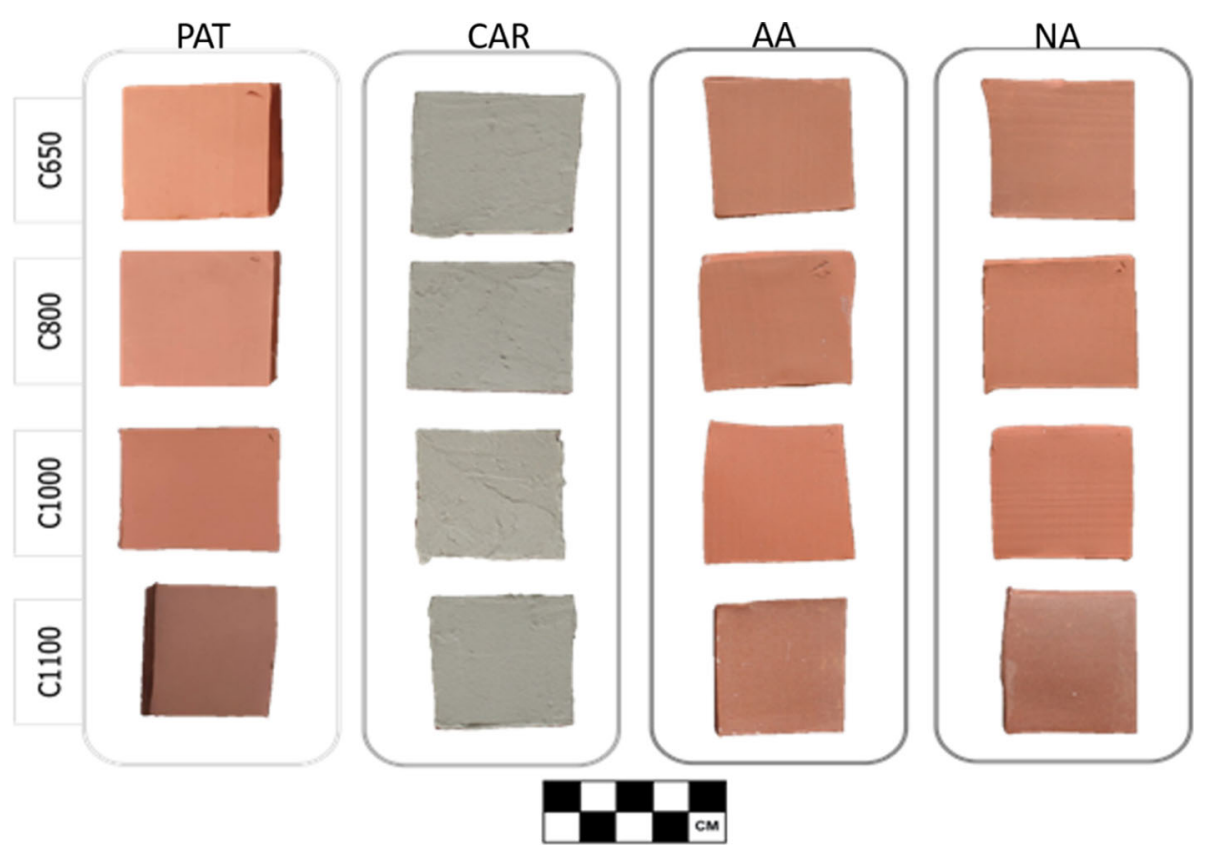

Fig. 3 The appearance of the pattern specimens' surface (PAT), carbonated specimens (CAR), treated specimens with acetic acid (AA) (c) and treated specimens with nitric acid (NA) (d)

Table 3 Monitoring of the neutralisation process in specimen C650 AA (see Table 2), treated with acetic acid by immersion

\begin{tabular}{llcccc}
\hline Ceramic mass $(\mathrm{g})$ & Water volume $(\mathrm{L})$ & Conductivity $\mathrm{K}(\mu \mathrm{S})$ & Time $(t, \mathrm{~min})$ & $K_{\text {norm }} 1$ & $K_{\text {norm } 2}$ \\
\hline 24.69 & 0.40 & 5.80 & 0 & 0.00 & 0.00 \\
24.69 & 0.40 & 15.40 & 5 & 44.79 & 17.73 \\
24.69 & 0.40 & 21.50 & 15 & 14.23 & 3.27 \\
24.69 & 0.40 & 24.60 & 30 & 4.82 & 1.87 \\
24.69 & 0.40 & 32.60 & 60 & 6.22 & - \\
24.69 & 0.40 & 37.70 & 120 & 1.98 & - \\
\hline
\end{tabular}

Time refers to the minutes in the deionised water bath and $K_{\text {norm }} 1$ refers to the first bath, $K_{\text {norm }} 2$ to the second, after a water renewal

where $\Delta K$ is the variation in conductivity, $L$ is the water volume in litres, $\Delta t$ is the time passed since the beginning of the process in days, and $g$ is the mass of the specimen to be neutralised in grams. According to White et al. [26], the process ends when the values of $K_{\text {norm }}$ are below or equal $2\left(K_{\text {norm }} \leq 2\right)$ (Fig. 4$)$. However, in this case, these values were reached much earlier, probably because the amount of salts was lower, so it was decided that the variable $K_{\text {norm }}$ should reach 2 twice, after renewing the water when the variable reaches 2 for the first time (Table 3 ). When this process ended, the ceramic specimens were introduced again into the climatic chamber at $20{ }^{\circ} \mathrm{C}$ and $50 \% \mathrm{RH}$ to let them dry for $24 \mathrm{~h}$. In Table 3 and Fig. 4 are gathered, as an example, the values of the neutralisation process of the specimen C650 treated with acetic acid (AA). 


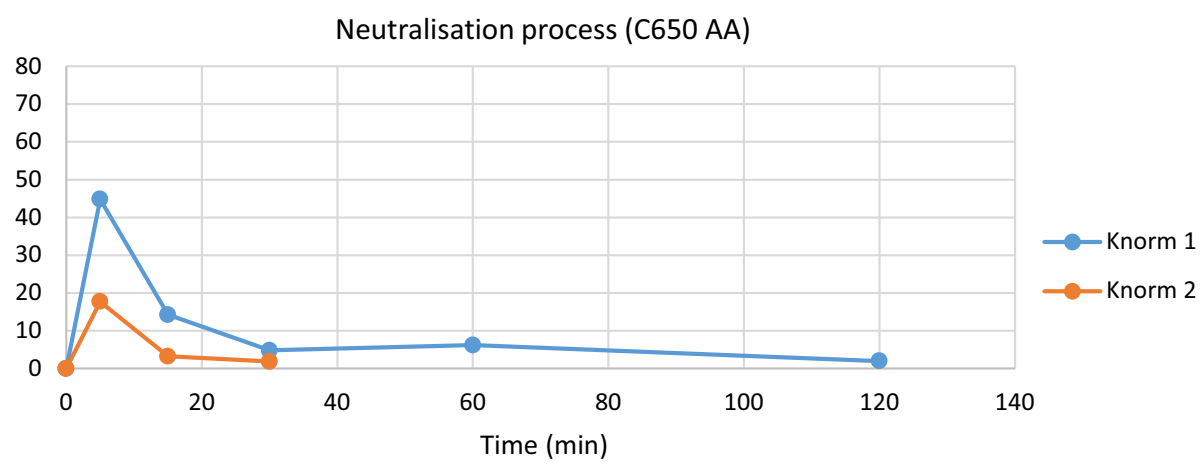

Fig. 4 Monitoring of the neutralisation process in specimen C650 AA (see Table 2), treated with acetic acid by immersion. Variation in time of the variable $K_{\text {norm }}$

\subsection{Chemical and mineralogical composition}

The chemical composition of the clay was determined by X-ray fluorescence (XRF) with a Panalytical Zetium equipment, and the results obtained were analysed with the software Omnian ${ }^{\circledR}$ (Panalytical). The analysis of oriented aggregates (OA) of the clay was pursued with a Bruker D8 ADVANCE equipment in Bragg-Bretano $\theta-\theta$ configuration $(\mathrm{Cu} \mathrm{K} \alpha$ radiation, $40 \mathrm{kV}, 40 \mathrm{~mA}$, angular range $2^{\circ}-35^{\circ}(2 \theta)$ with a step of $0.02^{\circ}$ and $0.8 \mathrm{~s}$ counting time). However, mineralogical changes were determined by XRPD.

One ceramic specimen of each firing temperature $\left(650,800,1000,1100{ }^{\circ} \mathrm{C}\right)$ was chosen as patterns and analysed before the carbonation process. The ceramic specimens cleaned with the treatments tests were also analysed. Their mineralogical composition was studied by Xray powder diffraction (XRPD) with a Panalytical X'Pert MPD equipment in Bragg-Bretano $\theta-\theta$ configuration $\left(\mathrm{Cu} \mathrm{K} \alpha\right.$ radiation, $45 \mathrm{kV}, 40 \mathrm{~mA}$, angular range $5^{\circ}-70^{\circ}(2 \theta)$ with a step of $0.02^{\circ}$ and $1 \mathrm{~s}$ counting time). For this purpose, fragments of the ceramics were finely grinded with an agate mortar. The phase identification was conducted using the PDF-2 2002 ICDD database using the HighScore Plus ${ }^{\circledR}$ software. Besides, mineralogical composition of the soil used for the carbonation process was also determined with XRPD and OA techniques.

Thermogravimetric (TG-DSC) analyses were also carried out to establish variations in the content of the calcium carbonate $\left(\mathrm{CaCO}_{3}\right)$ after the carbonation process and after the cleaning treatments, in comparison with the non-treated patterns. A simultaneous thermal analysis equipment SDT Q600 (TA ${ }^{\circledR}$ Instruments) was used; $10 \mathrm{mg}$ of powder samples was analysed in platinum capsule at a heating rate of $10^{\circ} \mathrm{C} / \mathrm{min}$, from room temperature to $1000^{\circ} \mathrm{C}$ in nitrogen atmosphere with a $100 \mathrm{~mL} / \mathrm{min}$ flow. The results obtained were analysed with TA Universal Analysis ${ }^{\circledR}$ software.

\section{Results and discussion}

\subsection{X-ray fluorescence of the commercial clay}

The XRF results provided by the supplier enterprise J. L. Vicentiz, S. L. (Table 1), were verified and completed. The data obtained shown high similarity, as the main components and quantities agreed. However, a semiquantitative analysis was conducted and its trace 
Table 4 XRF results expressed in oxides and ppm of the red commercial clay used for the elaboration of the ceramic specimens

\begin{tabular}{lllllllllll}
\hline \multicolumn{2}{l}{ Oxides \% } \\
\hline $\mathrm{SiO}_{2}$ & $\mathrm{Al}_{2} \mathrm{O}_{3}$ & $\mathrm{Fe}_{2} \mathrm{O}_{3}$ & $\mathrm{CaO}$ & $\mathrm{K}_{2} \mathrm{O}$ & $\mathrm{MgO}$ & $\mathrm{TiO}_{2}$ & $\mathrm{Na}_{2} \mathrm{O}$ & $\mathrm{P}_{2} \mathrm{O}_{5}$ & $\mathrm{MnO}$ & L.O.I \\
\hline 57.35 & 21.44 & 6.81 & 6.06 & 4.00 & 2.97 & 0.84 & 0.28 & 0.15 & 0.10 & 10.14 \\
\multicolumn{2}{l}{$\begin{array}{l}\text { Trace elements (ppm) } \\
\mathrm{Ba}\end{array} \mathrm{Zr}$} & $\mathrm{Sr}$ & $\mathrm{Rb}$ & $\mathrm{Cl}$ & $\mathrm{Zn}$ & $\mathrm{Co}$ & $\mathrm{Cr}$ & $\mathrm{Ni}$ & $\mathrm{Br}$ & $\mathrm{Pb}$ \\
862.9 & 171.2 & 151.4 & 147.5 & 127.3 & 93.6 & 83.9 & 76.1 & 70.0 & 64.1 & 60.2 \\
$\mathrm{Cu}$ & $\mathrm{Y}$ & $\mathrm{Ga}$ & $\mathrm{Nb}$ & & & & & & & \\
51.3 & 26.1 & 23.6 & 17.3 & & & & & & & \\
\hline
\end{tabular}

L.O.I.: Loss on Ignition

elements were identified. Table 4 shows the results obtained both of the major and minor components and trace elements.

\subsection{X-ray powder diffraction}

The XRPD pattern of the clay used for the ceramic specimens is shown in Fig. 5. Significant amount of quartz, $\left(\mathrm{SiO}_{2}\right)$ [JCPDS 01-086-1629] has been identified, together with phyllosilicates (muscovite $\left(\mathrm{KAl}_{3} \mathrm{Si}_{3} \mathrm{O}_{10}(\mathrm{OH})_{2}\right)$ [JCPDS 01-076-0929] and/or illite $\mathrm{KAl}_{2}\left(\mathrm{Si}_{3} \mathrm{Al}\right) \mathrm{O}_{10}(\mathrm{OH})_{2}$ [JCPDS 00-043-0685] and clinochlore $\left((\mathrm{Mg}, \mathrm{Fe})_{6}(\mathrm{Si}, \mathrm{Al})_{4} \mathrm{O}_{10}(\mathrm{OH})_{8}\right)$ [JCPDS 00-029-0701]), feldspar (albite $\mathrm{Na}\left(\mathrm{AlSi}_{3} \mathrm{O}_{8}\right.$ ) [JCPDS 01-071-1150] and orthoclase $\left(\mathrm{K}\left(\mathrm{AlSi}_{3} \mathrm{O}_{8}\right)\right)$ [JCPDS 01-076-0749]), and other minerals as hematite, $\left(\mathrm{Fe}_{2} \mathrm{O}_{3}\right)$ [JCPDS 01085-0599] (Fig. 5). Some amount of calcite $\left(\mathrm{CaCO}_{3}\right)$ [JCPDS 01-072-1651]) and dolomite $\left(\mathrm{CaMg}\left(\mathrm{CO}_{3}\right)_{2}\right)$ [JCPDS 01-073-2361], were also detected. Among phyllosilicates, the main components were determined by oriented aggregates patterns (OA). According to the results, mica-illite $(60 \%)$ and smectite $(25 \%)$ were the main phases, along with chlorite $(8 \%)$ and kaolinite $(7 \%)$ in minor concentration.

Besides, the XRPD patterns of the ceramic specimens fired at different temperatures are also included in Fig. 5. The peaks corresponding to phylosillicates (muscovite and/or illite) decreased with the rise in temperature and disappear at $1000^{\circ} \mathrm{C}$. Orthoclase main peak $\left(26.9^{\circ}\right)$ reduces its intensity and disappears at temperatures above $800{ }^{\circ} \mathrm{C}$. Clinochlore disappears before reaching $650{ }^{\circ} \mathrm{C}$. Anorthite is detected at $1000{ }^{\circ} \mathrm{C}$ and increases its diffraction peaks at higher temperatures $[27,28]$. In the same way, the maximum peaks of hematite became more intense and narrow as the firing temperature increased, probably due to a crystalline growth [7]. The decomposition of calcite begins above $650{ }^{\circ} \mathrm{C}$ and disappears above $800{ }^{\circ} \mathrm{C}$. Quartz remains the most abundant phase at all temperatures. The existence of an amorphous phase is evidenced by the increased background noise at temperatures above $800{ }^{\circ} \mathrm{C}$, which suggests that samples are undergoing vitrification.

Besides, the mineralogical composition of the soil from Guarrazar used for the growth of the artificial deposits was analysed. In the XRPD patterns, quartz [JCPDS 01-089-1961], calcite [JCPDS 01-081-2027], phyllosilicates as dickite [JCPDS 01-074-1758] and clinochlore [JCPDS 01-079-1270] were identified. Also plagioclases as anorthite [JCPDS 01-086-1707] and albite [JCPDS 01-076-0898] were detected. The analysis of oriented aggregates of the phyllosilicates (OA) determined its composition by: mica-illite (78\%), smectite (12\%), chlorite $(5 \%)$ and kaolinite $(5 \%)$. 


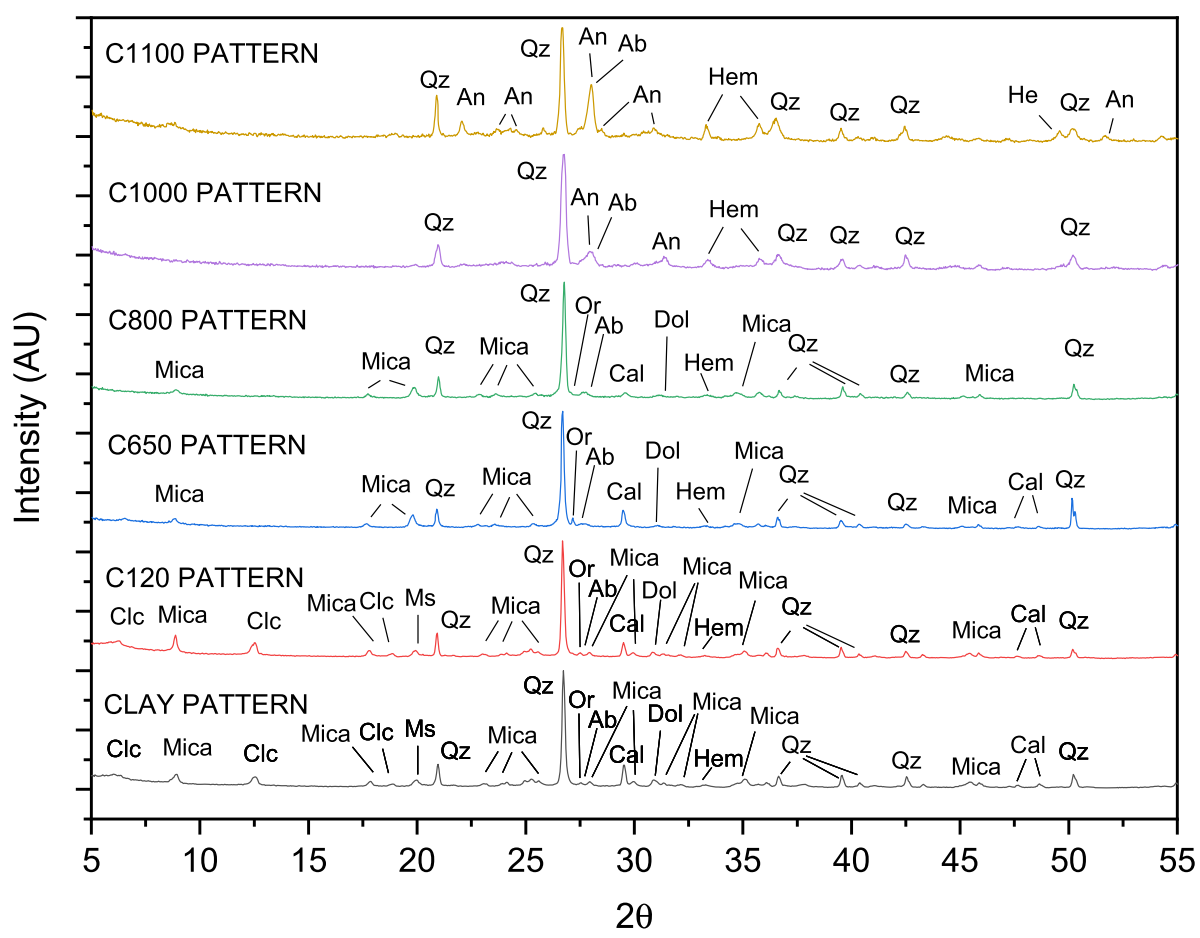

Fig. 5 Diffraction patterns of specimen patterns of the unfired clay and specimens fired at five temperatures $\left(120,650,800,1000\right.$ and $\left.1100^{\circ} \mathrm{C}\right)$. Ab: albite; An: anorthite; Cal: calcite; Clc: clinochlore; Dol: dolomite; Hem: hematite; Mica: muscovite and/or illite; Or: orthoclase; Qz: quartz

All the clay specimens were studied again after the cleaning treatments, showing no differences in any of the mineralogical phases detected (Fig. 6). Indeed, calcite peaks are detected, in both C650 and C800 specimens, which suggest that the acid treatments did not dissolve the carbonates from the ceramic. However, the semi-quantification of calcium carbonate content was made by the thermogravimetric analysis.

\subsection{Thermogravimetric analysis}

TG-DSC curves were evaluated considering both the mass loss expressed as percentage and the heat flow of samples as a function of temperature.

In all the thermograms, there was an endothermic peak at $573{ }^{\circ} \mathrm{C}$, which did not imply a weight loss, related to the polymorphic inversion of $\alpha$ quartz [29].

Another endothermic peak raised at $\sim 400{ }^{\circ} \mathrm{C}$, both in pattern (Fig. 7a) and carbonated specimens (Fig. 7b). This peak is ascribed to the loss of structurally bound water [30-32]. In the pattern samples, this peak is observed only in samples fired at low temperature (C650 and C800) and is linked to a small weight loss. Together with the results of XRPD data, this peak is ascribed to dehydroxylation of muscovite [33]. On the other hand, at this temperature range $\left(380-430{ }^{\circ} \mathrm{C}\right)$, another endothermic peak is observed in all the carbonated samples, no matter the firing temperature (Fig. 7b). From the derivative curve, within this temperature range, it is possible to observe two overlapped peaks in the samples fired at low temperature (C650 and C800), and only one in the samples fired at high temperature (C1000 and C1100), 

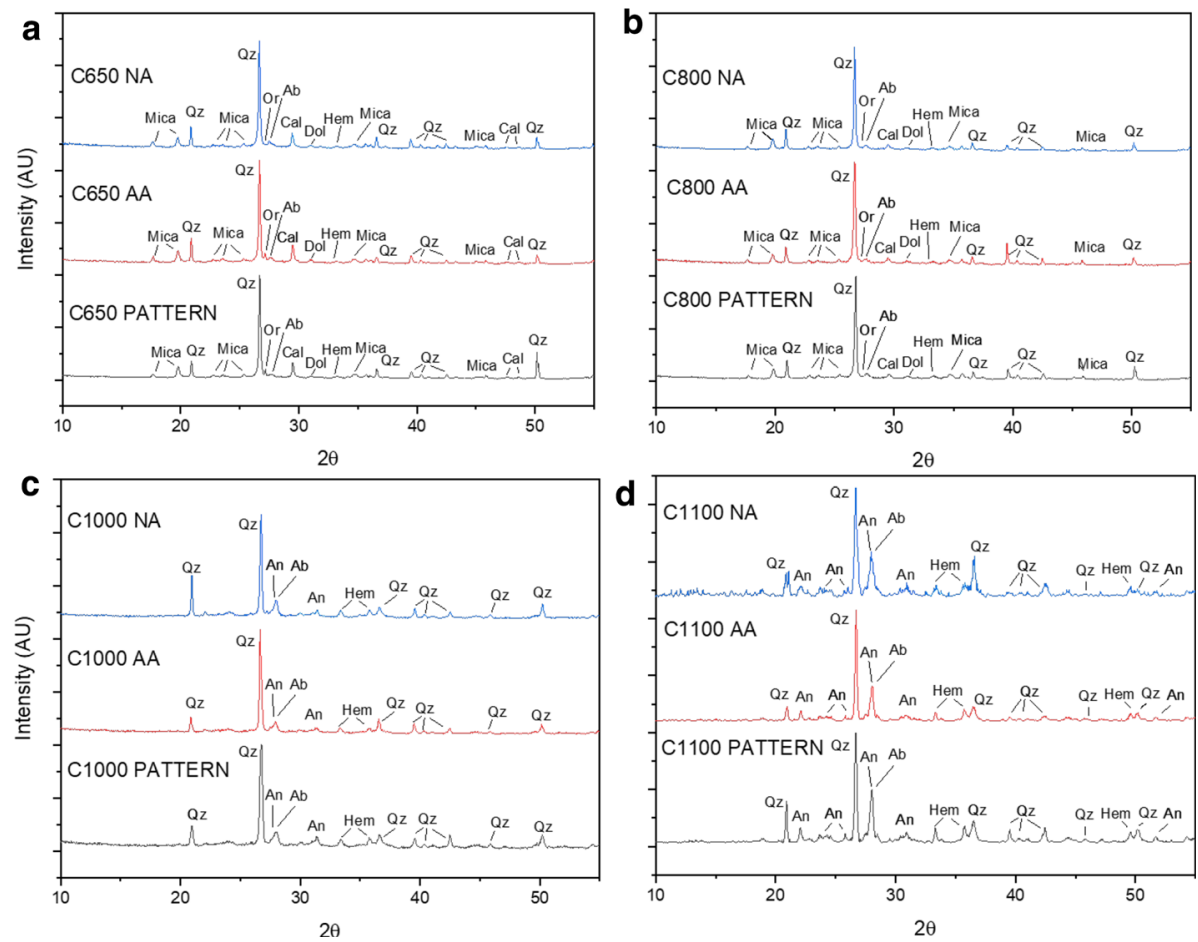

Figs. 6. Diffraction patterns of ceramic pattern specimens (PAT) and treated specimens (AA and NA) fired at the four temperatures: a $650{ }^{\circ} \mathrm{C}, \mathbf{b} 800{ }^{\circ} \mathrm{C}$, c $1000^{\circ} \mathrm{C}$ and $\mathbf{d ~} 1100{ }^{\circ} \mathrm{C}$. Ab: albite; An: anorthite; Cal: calcite; Dol: dolomite; Hem: hematite; Mica: muscovite and/or illite; Or: orthoclase; Qz: quartz

both linked to a weight loss. The first one can be ascribed to the dehydroxylation of calcium hydroxide [34], present in all samples, whereas the second one, to the dehydroxylation of muscovite [33], as determined in pattern samples and according to XRPD data. This would mean that during the carbonation process, not all of the calcium hydroxide $\left(\mathrm{Ca}(\mathrm{OH})_{2}\right)$ applied was transformed into calcium carbonate $\left(\mathrm{CaCO}_{3}\right)$. The endothermic peak at $\sim 400{ }^{\circ} \mathrm{C}$ in the treated samples was only present in the specimens fired at low temperature (Fig. 8a, b) as happened in the pattern samples (Fig. 7), so that peak can be ascribed to the dehydroxylation of muscovite alone, meaning that the cleaning treatments were effective in the removal of the $\mathrm{Ca}(\mathrm{OH})_{2}$ present in the carbonated specimens. In DSC curves of pattern specimens C650 and $\mathrm{C} 800$ (Fig. 7a), an important endothermic peak appeared $\sim 655^{\circ} \mathrm{C}$ together with a weight loss around $500-750{ }^{\circ} \mathrm{C}$, related to the decarbonation of calcium carbonate $[30,32]$, which was in agreement with the XRPD results. On the other hand, pattern specimens fired at 1000 and $1100{ }^{\circ} \mathrm{C}$, did not show any transformation within this temperature range (Fig. 7a), confirming the absence of calcium carbonate in these samples, in consonance with XRPD results. Besides, all the carbonated specimens showed such peaks due to decomposition of calcium carbonate from the carbonation process (Fig. 7b). However, the weight losses linked to this peak were higher for C650 and C800 than those detected in C1000 and C1100 (Fig. 7b).

On the other hand, in thermograms of cleaned specimens (Fig. 8), features related to the decomposition of calcium carbonate were detected in all of them, but with lower magnitude as the firing temperature increases, with the exception of the highest firing temperature (C1100). 

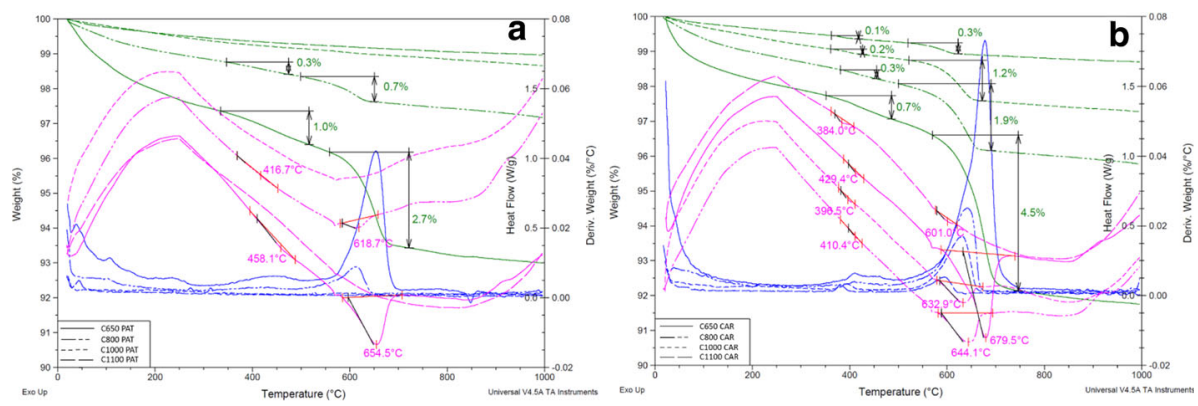

Fig. 7 On the left (a), thermograms of pattern specimens (PAT) and on the right (b), thermograms of carbonated specimens (CAR) for all the firing temperatures. In pink the heat flow $(\mathrm{W} / \mathrm{g})$ curve, in green the weight $(\%)$ and in blue the derived of the weight $\left(\% /{ }^{\circ} \mathrm{C}\right)$. The dehydroxylation of muscovite is detected $\sim 400{ }^{\circ} \mathrm{C}$, whereas the decarbonation process takes place $\sim 655^{\circ} \mathrm{C}$. The differences in the weight loss depend on the firing temperature specimens
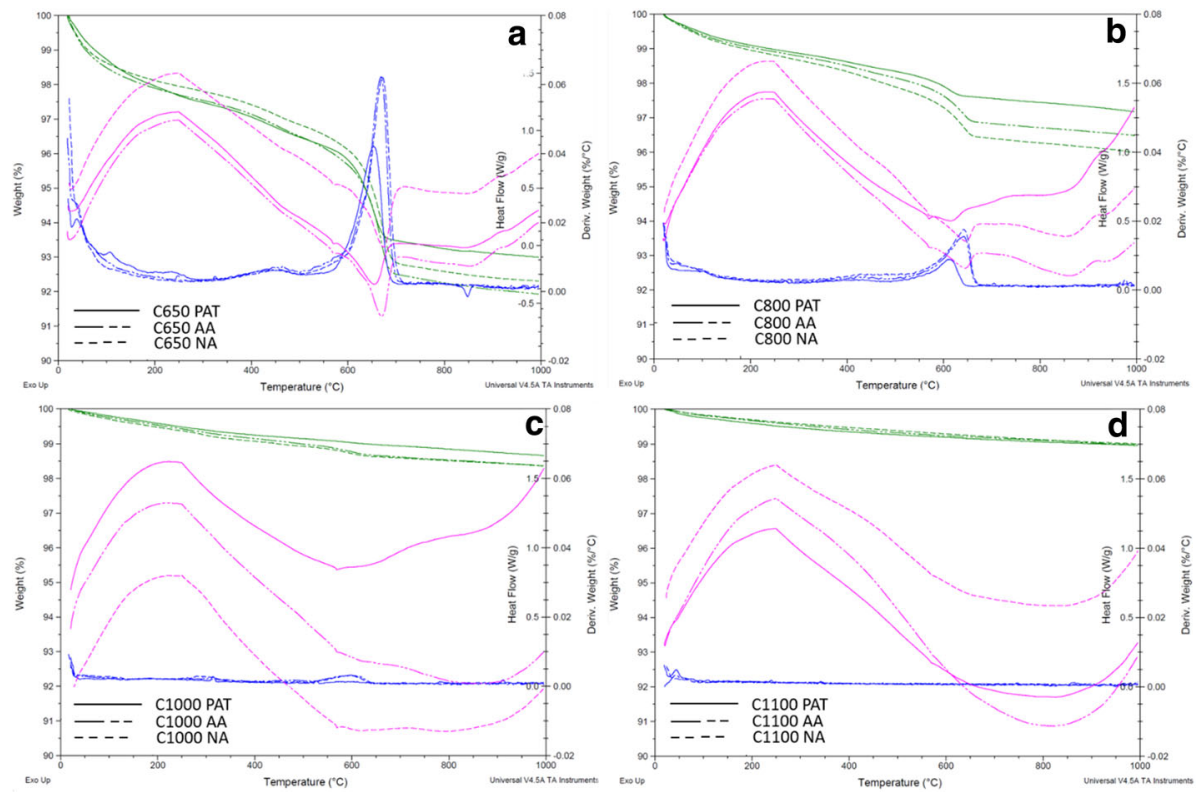

Fig. 8 Thermograms of all the specimens after the cleaning treatments, with acetic acid (AA) and nitric acid (NA): a $650{ }^{\circ} \mathrm{C}, \mathbf{b} 800{ }^{\circ} \mathrm{C}, \mathbf{c} 1000^{\circ} \mathrm{C}$ and d $1100{ }^{\circ} \mathrm{C}$. In pink the heat flow (W/g) curve, in green the weight $(\%)$ and in blue the derived of the weight $\left(\% /{ }^{\circ} \mathrm{C}\right)$. The thermograms show important differences regarding the firing temperature of the specimens. The decarbonation process is detected in C650 and C800 specimens both before and after the cleaning treatments. In the same way as that the dehydroxylation process

In the specimen C650 AA a weight loss of $3.9 \%$ between 532.6 and $738.4{ }^{\circ} \mathrm{C}$ was detected. In a similar way, another weight loss of $4.0 \%$ between 515.1 and $723.6^{\circ} \mathrm{C}$ was also detected in the specimen C650 NA (Fig. 8a). These weight losses detected at the temperature range 500-740 ${ }^{\circ} \mathrm{C}$ are higher than the weight loss detected in the pattern sample C650 PAT at the same temperature range $(2.7 \%$ ) (Fig. 7a). The same occurs for C800 treated samples, as after both treatments (AA and NA), a weight loss of $1.3 \%$ is detected between 502.4 and $675.2{ }^{\circ} \mathrm{C}$ for $\mathrm{C} 800 \mathrm{AA}$ and $525.9-677.8{ }^{\circ} \mathrm{C}$ for C800 NA (Fig. 8b). Also, for the specimens 
C1000 AA and 283 NA, a small weight loss of $0.3 \%$ is detected between 522.5 and 650.3 ${ }^{\circ} \mathrm{C}$ for AA, and between 517.1 and $640.9{ }^{\circ} \mathrm{C}$ for NA. However, the weight loss due to the decarbonation process is not detected in $\mathrm{C} 1100 \mathrm{AA}$ and NA specimens after the cleaning treatments (Fig. 8c, d), meaning that, for lower firing temperatures specimens (C650 and C800), the treatments were effective as they removed the artificial deposits, although there were still remains. Whereas for the highest firing temperature specimen $(\mathrm{C} 1100)$, the cleaning treatments have been more effective, as no remains of calcium carbonate were detected. On the other hand, the endothermic peaks related both to the dehydroxylation of muscovite and calcium hydroxide were noticeable after both acid treatments for the specimens fired at lower temperatures (Fig. 8a, b). However, it was not found in the thermograms of specimens fired at higher temperatures (Fig. 8c, d). So then, the cleaning treatments were effective in the removal of calcium hydroxide, and the peak found in specimens fired at lower temperatures was linked to the muscovite [32].

In addition, according to the results obtained from the thermogravimetric analysis, the approximate calcium carbonate content was calculated regarding the weight loss and the following reaction:

$$
\mathrm{CaCO}_{3}(100.01 \mathrm{~g})+\mathrm{Q}(\mathrm{J}) \rightarrow \mathrm{CaO}(56.07 \mathrm{~g})+\mathrm{CO}_{2}(44.01 \mathrm{~g})
$$

The results gathered in Table 5 determined that the calcium carbonate content in pattern specimens was higher for the lower firing temperatures, in agreement with XRPD data. Besides, the carbonation process was effective in the specimens fired at the four temperatures as the calcium carbonate content increased in all of them. However, this content decreased as long as the firing temperature increased. Besides, the calcium carbonate content did not decrease after the cleaning treatments in comparison with the pattern specimens. Indeed, there was a small increase in all cases with the exception in the specimen $\mathrm{C} 1100$. This increase might be due to the remains of the calcareous deposits generated after the carbonation process that were not completely removed by the cleaning treatments. However, they were not noticeable to human eye and do not interfere with the aesthetical values of the specimens.

From the data obtained, the remains of the calcareous deposits were established, calculated as the difference between the calcium carbonate content in carbonated and treated specimens. These contents were attached to the firing temperatures, as for both the acetic and the nitric acid treatments, the values were higher for C650 specimens and decreased along with the specimens fired at higher temperatures (Table 6). Besides, the efficacy of the treatments was calculated taking into account the removal of the artificial calcareous deposits after the acid treatments. For the sample fired at the lowest temperature, the largest deposit was observed $\left(4.1 \% \mathrm{CaCO}_{3}\right)$, and the efficacy resulted the lowest (33.3\% with AA and $27.8 \%$ with NA). As long as the deposit decreased, the efficacy of the treatments increased, reaching $100 \%$ efficacy in specimen C1100, both for acetic and nitric acid. Although 100\% efficacies were not reached in all the cases (Table 6), they were enough to make the remains unnoticeable to human eye. It is also important to point out that the efficacy of the treatments was very similar, even equal, for both acids tested.

\section{Conclusions}

According to the results, on one hand, the process followed for the elaboration of the specimens was a success, as well as the artificially growth of the surface deposits, as they both simulate archaeological ceramics characteristics. Regarding the carbonation process, calcium hydroxide $\left(\mathrm{Ca}(\mathrm{OH})_{2}\right)$ was detected by TG-DSC, in all the carbonated specimens, meaning 
Table 5 Weight loss and content of calcium carbonate in specimens at the four firing temperatures, pattern (PAT), carbonated (CAR) and after the treatments (AA, acetic acid; NA, nitric acid)
Table 6 Relative variation in the $\mathrm{CaCO}_{3}$ content $(\%)$ in the specimens fired at the four temperatures. Calculated efficacy of acid treatments

\begin{tabular}{llc}
\hline Specimen & Weight loss $(\%)$ at $\sim 655^{\circ} \mathrm{C}$ & $\% \mathrm{CaCO}_{3}$ \\
\hline C650 PAT & 2.7 & 6.1 \\
C650 CAR & 4.5 & 10.2 \\
C650 AA & 3.9 & 8.9 \\
C650 NA & 4.0 & 9.1 \\
C800 PAT & 0.7 & 1.6 \\
C800 CAR & 1.9 & 4.3 \\
C800 AA & 1.3 & 3.0 \\
C800 NA & 1.3 & 3.0 \\
C1000 PAT & - & - \\
C1000 CAR & 1.2 & 2.7 \\
C1000 AA & 0.3 & 0.7 \\
C1000 NA & 0.3 & 0.7 \\
C1100 PAT & - & - \\
C1100 CAR & 0.3 & 0.7 \\
C1100 AA & - & - \\
C1100 NA & - & - \\
\hline
\end{tabular}

\begin{tabular}{|c|c|c|c|c|}
\hline Specimen & C650 & C800 & $\mathrm{C} 1000$ & $\mathrm{C} 1100$ \\
\hline \multicolumn{5}{|l|}{$\% \mathrm{CaCO}_{3}$} \\
\hline Pattern (PAT) & 6.1 & 1.6 & - & - \\
\hline Carbonated (CAR) & 10.2 & 4.3 & 2.7 & 0.7 \\
\hline After acetic acid treatment (AA) & 8.9 & 3.0 & 0.7 & - \\
\hline After nitric acid treatment (NA) & 9.1 & 3.0 & 0.7 & - \\
\hline Artificial calcareous deposit & 4.1 & 2.7 & 2.7 & 0.7 \\
\hline Deposit remains after AA treatment & 2.7 & 1.4 & 0.7 & - \\
\hline Deposit remains after NA treatment & 3.0 & 1.4 & 0.7 & - \\
\hline $\begin{array}{l}\text { Efficacy of acetic acid treatments } \\
(\%)\end{array}$ & 33.3 & 50.0 & 75.0 & 100.0 \\
\hline $\begin{array}{l}\text { Efficacy of nitric acid treatments } \\
(\%)\end{array}$ & 27.8 & 50.0 & 75.0 & 100.0 \\
\hline
\end{tabular}

that the carbonation process was not concluded, as the calcium hydroxide applied on the ceramic surface was not completely transformed into calcite $\left(\mathrm{CaCO}_{3}\right)$. In addition, a correlation between the firing temperature and the growth of the deposits was found: the lower the firing temperature, the larger the deposit.

Besides, both acid treatments employed for the removal of calcareous deposits on ceramic specimens were effective, since the deposits were successfully removed as they are no longer noticeable to human eye. Even though, their efficacy varied and was linked to the amount of the deposit. For larger deposits, the efficacy decreased. However, it was proved that even with low efficacies $(\sim 30 \%)$, the deposits are not visible. For this reason, they would no longer interfere with the aesthetic values of the specimens. Besides, calcium hydroxide is not detected after the cleaning treatments, and due to the stability of calcite, the conservation of the specimens would not be jeopardise. 
Acknowledgements The authors gratefully acknowledge the research programme Top Heritage-CM (S2018/NMT-4372) and Interdisciplinary Thematic Platforms PTI-PAIS (CSIC). Also, the Research Assistance Centres (CAI) of Geological Techniques and X-ray Diffraction (UCM) and X-Ray Fluorescence (UGR), Palarq Foundation (PR2004_19/02) and the research group Cultural Heritage Documentation, Conservation and Restoration Techniques (UCM-930420). They also thank Complutense University of Madrid and Banco Santander for Águeda Sáenz-Martínez's PhD scholarship (CT17/17-CT18/17), Complutense University of Madrid for the postdoctoral position of Marta Pérez-Estébanez (CT39/17) and the Spanish Ministry of Science and Innovation for the Postgraduate Student's Scholarship at La Residencia de Estudiantes (2020-2021).

Funding Open Access funding provided thanks to the CRUE-CSIC agreement with Springer Nature.

Open Access This article is licensed under a Creative Commons Attribution 4.0 International License, which permits use, sharing, adaptation, distribution and reproduction in any medium or format, as long as you give appropriate credit to the original author(s) and the source, provide a link to the Creative Commons licence, and indicate if changes were made. The images or other third party material in this article are included in the article's Creative Commons licence, unless indicated otherwise in a credit line to the material. If material is not included in the article's Creative Commons licence and your intended use is not permitted by statutory regulation or exceeds the permitted use, you will need to obtain permission directly from the copyright holder. To view a copy of this licence, visit http://creativecommons.org/licenses/by/4.0/.

\section{References}

1. C. Orton, P. Tyers, A.G. Vince, La Cerámica En Arqueología (Crítica, Barcelona, 1997), pp. 26-38

2. B. Carrascosa, La conservación y restauración de objetos cerámicos arqueológicos (Tecnos, España, 2009)

3. G.M. Crisci, M.F. La Russa, M. MacChione, M. Malagodi, A.M. Palermo, S.A. Ruffolo, Appl. Phys. A. (2010). https://doi.org/10.1007/s00339-010-5661-9

4. F. Burriel, S. Arribas, J. Hernandez, F. Lucena, Química Analítica Cualitativa, 18th edn. (Ediciones Paraninfo, Madrid, 2003)

5. C. Caple, Conservation Skills : Judgement, Method and Decision Making (Routledge, London, 2000)

6. J.M. Cronyn, W.S. Robinson, The Elements of Archaeological Conservation (Routledge, London, 1990)

7. M.C. Berducou, J.P. Adam, La Conservation En Archéologie: Méthodes et Pratique de La ConservationRestauration Des Vestiges Archéologiques (Masson, Paris, 1990)

8. S. Buys, V. Oakley, The Conservation and Restoration of Ceramics (Butterworth-Heinemann, Oxford, 1993)

9. C. Fernández, Monte Buciero. 9 (2003)

10. C. Pearson, Conservation of Marine Archaeological Objects (Butterworth-Heinemann, Oxford, 1987)

11. N. Bonelli, D. Chelazzi, M. Baglioni, R. Giorgi, P. Baglioni, Nanosci. Cult. Herit. (2016). https://doi.org/ 10.2991/978-94-6239-198-7_10

12. E. Carretti, L. Dei, R.G. Weiss, P. Baglioni, J. Cult. Herit. (2008). https://doi.org/10.1016/j.culher.2007. 10.009

13. R. Giorgi, M. Baglioni, D. Berti, P. Baglioni, Acc. Chem. Res. (2010). https://doi.org/10.1021/ar900193h

14. D. Stulik, V. Dorge, H. Khanjian, N. Khandekar, A, Tagle, D. de, Miller, J. Carlson, Adv. Conserv. (2000) https://doi.org/10.1179/sic.2000.45.Supplement-1.188

15. A. Sáenz-Martínez, M. San Andrés, M. Alvarez de Buergo, I. Blasco, R. Fort. (2019) https://doi.org/10. 5281/zenodo.3583061

16. Unpublished report about currently treatments applied by Spanish conservators of different institutions.

17. M.P. Casaletto, G.M. Ingo, C. Riccucci, T. de Caro, G. Bultrini, I. Fragalà, M. Leoni, Appl. Phys. A. (2008). https://doi.org/10.1007/s00339-008-4519-x

18. M. Coladonato, B. Di Odoardo, E. Prunas, Proc. Chem. (2013). https://doi.org/10.1016/j.proche.2013. 03.009

19. J. S. Johnson. H. M. Erickson. H. Iceland. MRS Proceedings. (1995). https://doi.org/10.1557/PROC-352831

20. G. Cultrone, E. Sebastián, K. Elert, M.J. de La Torre, O. Cazalla, C. Rodriguez-Navarro, J. Eur. Ceram. Soc. (2004). https://doi.org/10.1016/S0955-2219(03)00249-8

21. O. S. Rye, Pottery technology: principles and reconstruction (Taraxacum Inc., Washington D.C., 1981)

22. S. Peterson, J. Peterson, Trabajar El Barro (Blume, Barcelona, 2003)

23. A. O. Shepard, Ceramics for the archaeologist (Carnegie Institute, Washington D.C., 1980) 
24. AENOR, Conservación de edificios. Limpieza de elementos constructivos. Parte 5-2: Técnicas de limpieza con agua. UNE 41806-2: 2009 IN (AENOR, Madrid, 2009)

25. J. Unruh, Stud. Conserv. (2001). https://doi.org/10.2307/1506839

26. C. White, M. Pool, N. Carroll, J. Am. Inst. Conserv. (2010). https://doi.org/10.1179/019713610804500564

27. G. Cultrone, C. Rodriguez-Navarro, E. Sebastian, O. Cazalla, M.J. De La Torre, Eur. J. Miner. (2001). https://doi.org/10.1127/0935-1221/2001/0013-0621

28. J. Linares, F. Huertas, J. Capel, Cuad Prehist Arqueol Gran (1983). http://revistaseug.ugr.es/index.php/ cpag/article/view/1224

29. D. James Dwight, C. J. Hurlbut, C. Klein, C.Manual de mineralogía de Dana, 3rd edn. (Reverté, Barcelona, 1990)

30. A. Arizzi, G. Cultrone, Constr. Build. Mater. (2012). https://doi.org/10.1016/j.conbuildmat.2011.12.069

31. C. Montoya, J. Lanas, M. Arandigoyen, Mater. Struct. (2004). https://doi.org/10.1007/BF02479640

32. A. Moropoulou, M. Apostolopoulou, P. Moundoulas, E. Aggelakopoulou, L. Siouta, A. Bakolas, P. G. Asteris, in Applied Sciences and Engineering, ed. By M. Papadrakakis, V. Papadopoulos, G. Stefanou, V. Plevris (Greece, 2016)

33. G.L. Gaines, W. Vedder, Nature (1964). https://doi.org/10.1038/201495a0

34. M. Khachani, A. El Hamidi, M. Halim, S. Arsalane, J. Mater. Environ. Sci. 5, 2 (2014) 